\title{
The automatic selection of hydraulic spray nozzles based on the psychrometric air conditions in hydropneumatic sprayers
}

\author{
Robson Shigueaki Sasaki ${ }^{*}$ (D), Ana Cláudia de Brito ${ }^{1}$, Cleyton Batista de Alvarenga ${ }^{2}$, \\ Mauri Martins Teixeira ${ }^{3}$,Helton John Alves Rocha ${ }^{l}$
}

$10.1590 / 0034-737 X 202067010002$

\begin{abstract}
The aim of the current study is to develop an electronic system capable of automatically replacing hydraulic spray nozzles, based on psychrometric air conditions such as temperature and relative air humidity, in order to help improving the efficiency of application technologies. The system comprised one microcontroller, two solenoid valves, one temperature and relative humidity sensor, and a control algorithm. The system was installed in a hydropneumatic sprayer adapted with two semi-arcs. One semi-arc was equipped with JA-2 and other semi-arc with CVIA-015 hydraulic nozzles. After the algorithm interpreted the momentary psychrometric air conditions, it activated the JA-2 (when VPD $<20 \mathrm{hPa}$ ) or the CVIA-015 nozzle (when VPD > $20 \mathrm{hPa}$ ). The system was evaluated based on technical spraying parameters and on the response time to replace the hydraulic nozzle. Based on the results, the smallest-diameter droplets were the most influenced by psychrometric air conditions. VPD $>20 \mathrm{hPa}$ tended to increase the VMD values and to reduce droplet density, although it did not change the SPAN index. The necessary mean time to switch from the JA-2 to the CVIA-015 nozzle was $0.742 \mathrm{~s}$, whereas the necessary mean time to switch from the CVIA-015 to the JA-2 nozzle was $0.684 \mathrm{~s}$.
\end{abstract}

Keywords: droplets spectrum; VPD; droplets evaporation.

\section{INTRODUCTION}

The efficient application of plant protection products is closely linked to the meteorological conditions at spraying time. According to Maciel et al. (2017a), up to $27 \%$ of the applied liquid volume may be lost depending on the operational condition. Yu et al. (2009), Xu et al. (2010) and Cunha et al. (2016), observed that the lower the relative air humidity, the higher the droplet evaporation rate, i.e., the evaporation time is associated with droplet diameter. In other words, the largest droplets require more time to evaporate. Sasaki et al. (2016) evaluated the VPD effect on hydraulic air-assisted bar sprays and found that high VPD conditions favored losses caused by spray droplet evaporation.
Although the effect of the psychrometric air conditions at spraying time is well-known, the pressure resulting from the incidence of pests and diseases in the field does not always allow meeting the ideal range of saturated watervapor pressure deficit (VPD) in the air for the application of plant protection products. In some cases, producers demand product application under unfavorable conditions, mainly due to rainfall or mechanical problems. Sometimes, operators start the application procedure under optimum VPD conditions, which often happen at dawn. However, ambient air tends to get warmer and relative humidity gets lower as the hours progress; in this case, the droplet size must be increased in order to minimize evaporation-related losses, according to Alvarenga et al. (2013). Replacing the hydraulic nozzle without changing

\footnotetext{
Submitted on August 15 th, 2018 and accepted on December $9^{\text {th }}, 2019$

'Instituto Federal de Minas Gerais, Departamento de Engenharia e Computação, Bambuí, Minas Gerais, Brazil. robson.sasaki@ifmg.edu.br; anabritoagro.08@gmail.com; helton.alves@ifmg.edu.br

${ }^{2}$ Universidade Federal de Uberlândia, Instituto de Ciências Agrárias, Monte Carmelo, Minas Gerais, Brazil. cleytonalvarenga@ufu.br

${ }^{3}$ Universidade Federal de Viçosa, Departamento de Engenharia Agrícola, Viçosa, Minas Gerais, Brazil. mauri@ufv.br

* Corresponding author: robson.sasaki@ifmg.edu.br
} 
the spray volume in hydraulic and hydropneumatic sprayers is an adjustment alternative.

Air-induction spray nozzles can be an alternative in case of extreme psychrometric conditions. According to Ferguson et al. (2015), besides other features, these nozzles have a pre-orifice chamber able to increase the droplet size; thus, they enable applications under a wide range of environmental conditions.

However, changing the droplet spectrum through nozzle replacement requires knowledge about spraying, operator qualification, besides the constant monitoring of weather conditions, which is not a routine practice in many farms. According to Queiroz \& Reis (2015), it is essential conducting continuous studies about techniques capable of minimizing agricultural losses caused by water evaporation in hydraulic applications to help reducing costs and environmental contamination.

Thus, the aim of the current study was to develop an electronic system capable of automatically replacing hydraulic spray nozzles in hydropneumatic sprayers, based on the psychrometric air conditions at spraying time and evaluate the system developed for technical parameters and spray quality.

\section{MATERIAL AND METHODS}

The study was conducted in the Machinery and Agricultural Mechanization Laboratory of Minas Gerais Federal Institute, Bambuí Campus.

The automatic nozzle exchange system comprised one microcontroller (Duemilanove model, Arduino, Strambino, Italy), two solenoid valves (VA-03 model, Marcoval ${ }^{\circledR}$, São Paulo, SP, Brazil), and one temperature and relative humidity sensor (DH-11 model, Geeetech ${ }^{\circledR}$, Shenzen, China).

We developed an algorithm using the $\mathrm{C}++$ language, after assembling the electronic circuit. It allowed interpreting stimuli deriving from sensor readings as strain signals proportional to the psychrometric air conditions. These signals were converted into temperature $\left({ }^{\circ} \mathrm{C}\right)$ and relative humidity (\%). First, temperature was the variable used to set the water vapor saturation pressure in the air (Equation 1).

$\mathrm{e}_{\mathrm{S}}=6.108 \times 10^{\left[\frac{(7.5 \mathrm{t})}{(237.5+\mathrm{t})}\right]}$

wherein

$\mathrm{e}_{\mathrm{s}}=$ water vapor saturation pressure in the air $(\mathrm{hPa})$; and, $\mathrm{t}=$ air temperature $\left({ }^{\circ} \mathrm{C}\right)$.

Next, we used relative air humidity data to set the partial water vapor pressure (Equation 2).

$\mathrm{e}_{\mathrm{a}}=\frac{\mathrm{RH} \mathrm{e}_{\mathrm{s}}}{100}$ wherein

$\mathrm{e}_{\mathrm{a}}=$ partial water vapor pressure in the air $(\mathrm{hPa})$; and,

$\mathrm{RH}=$ relative air humidity $(\%)$.

Finally, we set the water vapor saturation pressure deficit in the air (Equation 3).

$\mathrm{VPD}=\mathrm{e}_{\mathrm{s}}-\mathrm{e}_{\mathrm{a}}$

VPD was monitored every second. We calculated the mean VPD every 15 seconds, or 15 readings, for decisionmaking purposes: the first solenoid valve remained open and the second one remained closed when the mean VPD was lower than $20 \mathrm{hPa}$. The opposite happened when the mean VPD was higher than $20 \mathrm{hPa}$ (Figure 1).

After the algorithm was prepared, the electronic system was embedded in a hydropneumatic sprayer equipped with semi-arc-shaped bar and 8 hydraulic nozzles in each side (Arbus 400725 model, Jacto ${ }^{\circledR}$, Pompéia, Brazil), 725 mm fan diameter, JP-75 pump (75 $\mathrm{L} \mathrm{min}^{-1}$ flow and maximum working pressure $300 \mathrm{psi}$, maximum fan rotation $1,900 \mathrm{rpm}$, air flow speed $26 \mathrm{~m} \mathrm{~s}^{-1}$, and air volume $5 \mathrm{~m}^{3} \mathrm{~s}^{-1}$ ) (Figure 2A).

We installed an additional semi-arc adjacent to the original one to enable system installation. Thus, the sprayer was left with two semi-arcs: one equipped with hydraulic nozzles presenting hollow-cone profile and medium-to-fine droplets (JA-2 model, Jacto ${ }^{\circledR}$, Pompéia, SP, Brazil) and the other with air-induction hydraulic nozzles presenting hollow-cone profile and coarse to extremely coarse droplets (CVIA-015 model, MagnoJet ${ }^{\circledR}$, Ibaiti, PR, Brazil) (Figure 2B). We placed the temperature and relative air humidity sensor in a shelter adjacent to the tractor cabin. Each valve was installed adjacent to its respective spray semi-arc: valve one was connected to the semi-arc with JA-2 nozzles and valve two was connected to the semi-arc with CVIA-015 nozzles.

The system was evaluated by taking into consideration technical spraying parameters (liquid flow, VMD, droplet density and SPAN index) and the system response time.

We used a graduated cylinder ( $20 \mathrm{~mL}$ resolution) and a pressure gauge kit for hydropneumatic sprayers $(0.002 \mathrm{kPa}-$ resolution manometer) installed adjacent to a hydraulic nozzle in the liquid flow test to measure the flow of the 8 hydraulic nozzles in each semi-arc, at pressures 300; 400; 500 and $600 \mathrm{kPa}$. Each nozzle and pressure were subjected to three repetitions.

The study followed a completely randomized design with factorial arrangement $2 \times 2 \times 3$ (2 spray nozzle models (JA-2 and CVIA-015), 2 water vapor saturation pressure deficits $(<20$ and $>20 \mathrm{hPa})$, and 3 target distances $(0.5,1.0$ and $1.5 \mathrm{~m}$ ), with 4 repetitions per treatment in order to evaluate the technical spraying parameters. 
The automatic system was responsible for target applications using the JA-2 hydraulic nozzle at VPD $<20$ $\mathrm{hPa}$, and the CVIA- 015 one at VPD $>20 \mathrm{hPa}$, to enable data acquisition. The automated nozzle selection system was turned off under the following conditions: JA-2 hydraulic nozzle at VPD > $20 \mathrm{hPa}$ and CVIA-015 hydraulic nozzle at $\mathrm{VPD}<20 \mathrm{hPa}$, and the application was based on the conventional system. We conducted this test under laboratory conditions in a room with paved floor. We applied the spray in artificial targets (hydrosensitive labels) fixed on a pedestal. The experimental unit in each data acquisition procedure comprised 3 hydrosensitive labels to help minimizing errors.

We adjusted sprayer pressure to the system flow, regardless of the hydraulic nozzle model; the working pressure in this case was $300 \mathrm{kPa}$. We used a John Deere tractor (5603 model, Montenegro, RS, Brazil) at operating speed $8.06 \mathrm{~km} \mathrm{~h}^{-1}$ to drive the mechanized set.

After the spraying sessions were over, the labels were taken to the laboratory and immediately photographed in a Sony digital camera (HX1 model). We used the ImageTool 3.0 software to set technical spraying parameters such as VMD, droplet density and SPAN index.

The methodology described by Pereira (2006) was used to evaluate the electronic system response time. A Sony digital camera (HX1 model) was our tool of choice to record the vicinities of the hydraulic nozzle, whereas an electric air heater placed near the temperature and relative humidity sensor simulated different psychrometric conditions to induce the automatic replacement of the JA-2 nozzle by

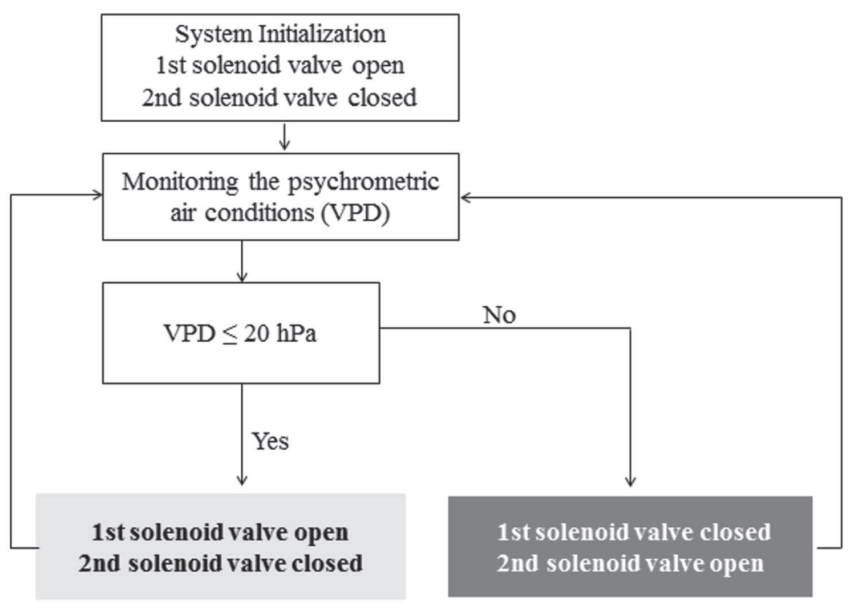

Figure 1: Logic of the automatic control algorithm applied to the hydraulic nozzle replacement system based on psychrometric air conditions.

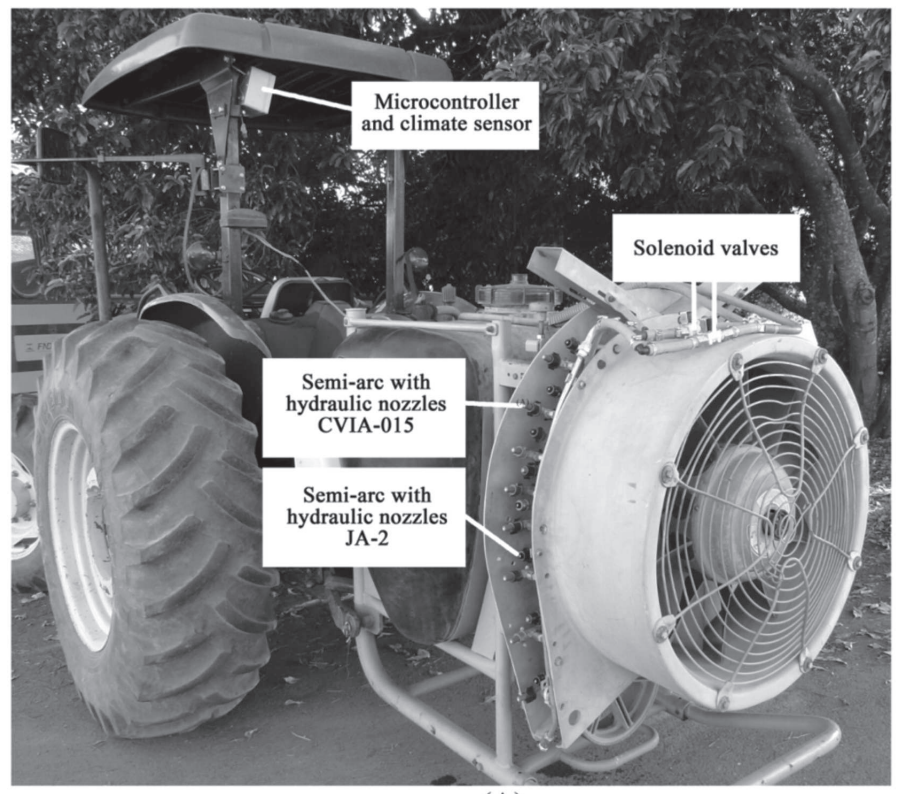

(A)

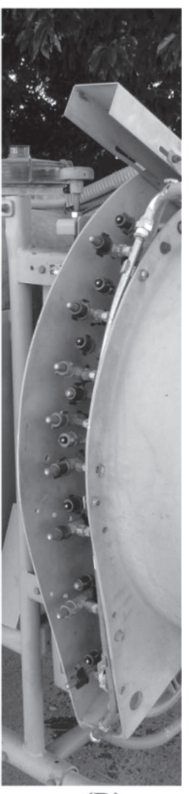

(B)

Figure 2: Embedded electronic system for the automatic replacement of spray nozzles in hydropneumatic sprayers. (A) Complete system; (B) Semi-arcs adapted with hydraulic nozzles. 
the CVIA-015 hydraulic nozzle and vice versa. Subsequently, we used the VideoPad software (version 2.41) to convert the film into frames. The necessary time to replace one nozzle by the other was determined based on the data acquisition frequency at the recording time. Nozzle replacements happened simultaneously in one semi-arc; however, we recorded all 8 nozzles of the semi-arc, and performed the same procedure four times, in order to minimize the errors.

We subjected the collected data to analysis of variance in the $\mathrm{F}$ test $(\mathrm{P}<0.05)$. Qualitative factor means were compared through the Tukey test $(\mathrm{P}<0.05)$, whereas the quantitative ones were subjected to linear regression; the significance of coefficients was checked through t test and coefficient of determination. We performed all analyses in the Sisvar ${ }^{\circledR}$ software v.5.3 (Ferreira, 2011).

\section{RESULTS AND DISCUSSION}

The JA-2 and CVIA-015 nozzles, at $300 \mathrm{kPa}$, presented mean flow 0.612 and $0.592 \mathrm{~L} \mathrm{~min}^{-1}$, respectively, in the liquid flow evaluation. In addition, the liquid flow increased as the working pressure increased (Figure 3).

The herein recorded liquid flow behavior corroborates the studies by Gandolfo et al. (2014) and Maciel et al. (2017b), who evaluated other hydraulic nozzle models. However, Alvarenga et al. (2013) analyzed JA-2 nozzles and recorded significantly reduced effect of pressures higher than 1,055 kPa on droplet size. Consequently, they recorded higher energy expenditure, nozzle wear, ruptures in hoses, connections and filters, and small droplet size increase.
Table 1 shows the psychrometric air conditions during the tests conducted to evaluate the technical spraying parameters.

Based on the volumetric-median diameter results, the CVIA-015 nozzle presented larger-diameter droplets than the JA-2 one. This behavior was already expected, since the CVIA-015 is an air-induction spray nozzle. Increased VPD lead to increased VMD values in a given target distance and nozzle model (Table 2). The distance analysis applied to a given hydraulic nozzle under a certain VPD condition did not show correlation between variables and VMD.

Based on the conditions adopted in our study, changes in the VPD may have led to droplet evaporation and changed the VMD values due to the extinction of a large number of fine droplets. According to Maciel et al. (2016), the diameter of spray droplets increased as the VPD increased. Droplet density results may justify this hypothesis, since the droplet density at the target decreased as the VPD increased in all tests (Table 3).

According to the VPD effect analysis, the droplet density decreased by $30.5 \%, 4.9 \%$ and $24.3 \%$ at target distances $0.5 \mathrm{~m}, 1.0 \mathrm{~m}$ and $1.5 \mathrm{~m}$, respectively, when the VPD increased in the JA-2 nozzle. Our results corroborate the study by Alvarenga et al. (2014), who also found droplet density decrease as the VPD increased. The largest target deposition decrease recorded in our study was observed when the JA-2 nozzle was $0.5 \mathrm{~m}$ away from the target. We expected to find the most prominent decrease at greater target distances, since the droplet-air contact time would be longer and, consequently, the evaporation likelihood would increase. However, this outcome was not

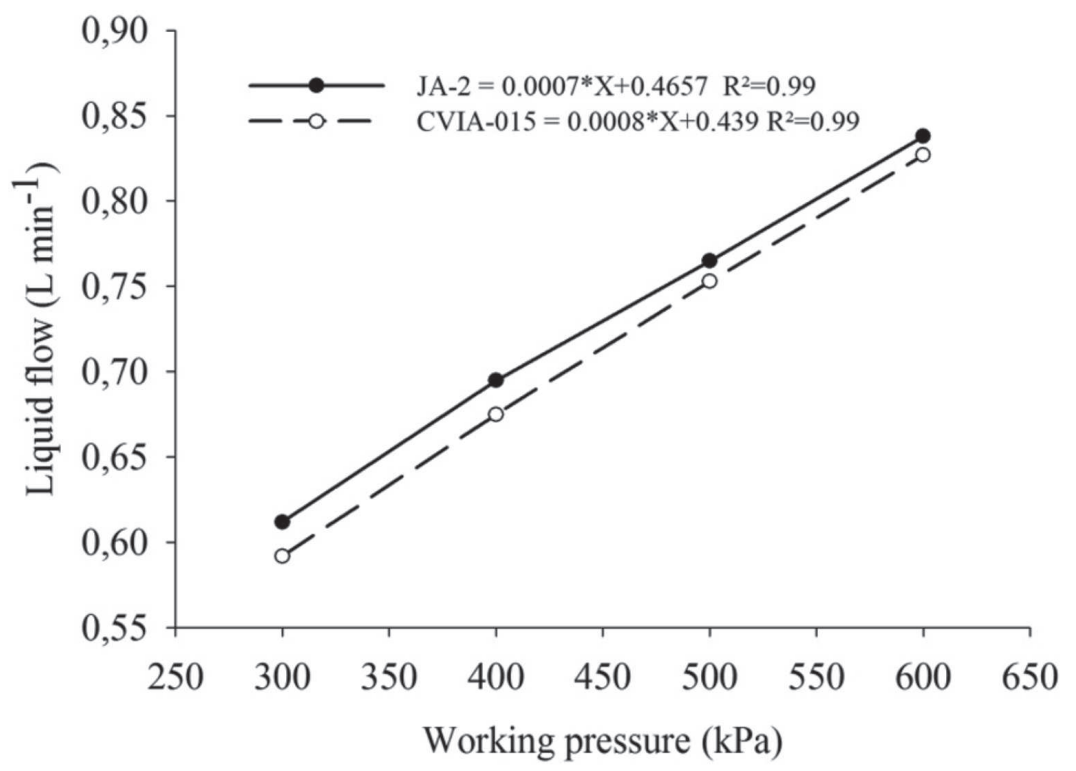

Figure 3: Liquid flow enabled by JA-2 and CVIA-015 hydraulic nozzles under different operating conditions. 
observed. As the VPD increased in the CVIA-015 nozzle, the droplet density decreased by $11.4 \%, 12.9 \%$ and $13.6 \%$ at target distances $0.5 \mathrm{~m}, 1.0 \mathrm{~m}$ and $1.5 \mathrm{~m}$, respectively.

According to the distance analysis applied to different hydraulic nozzles and VPDs, the droplet density tended to decrease as the target distance increased, regardless of the condition (Figure 4).

Droplets are carried by the airflow in hydropneumatic sprayers. The air speed decreases as the distance increases and it leads to reduced target deposition. Smaller droplets are carried more easily. It means that the distance between lines in the field can affect the deposition on the target and the droplet penetration in the canopy.

The test results highlighted the importance of sprayer automation based on the psychrometric air conditions at application time. Coarse droplets are susceptible to psychrometric air conditions (Maciel et al, 2018) - although in smaller proportions - in comparison to fine droplets, fact that corroborates the study by Cunha et al. (2016).

The SPAN index has dimensionless value and indicates the droplet spectrum uniformity (Creech et al, 2015). The statistical tests applied to this parameter presented nonsignificant values in all cases: the parameter ranged from 0.92 to 1.18 for the JA-2 nozzle and from 0.93 to 1.20 for the CVIA-015 one (Table 4).

With respect to pesticide application, the more homogeneous the droplet spectrum, the closer to zero the SPAN index value and the stronger the probability of increasing the application efficiency. It happens because the VMD parameter alone is most often taken into consideration at the time to plan the droplet size.

As for the system response time, the necessary mean time to replace the JA- 2 nozzle by the CVIA-015 one was $0.742 \mathrm{~s}$, whereas the mean time to replace the CVIA-015 nozzle by the JA- 2 one was $0.684 \mathrm{~s}$. The system presented field spray applicability and short hydraulic nozzle replacement time. Alvarenga et al. (2013) developed an automatic droplet spectrum control system based on servomotors and reported that other systems based on electric valves can present more viable response time. In the present study, the response times obtained shorter than the ones recorded by Machado et al. (2015) for other automated spray systems.

Changing the droplet spectrum in the manual system requires skilled labor and operation interruption; therefore, it ends up being ignored. Automatic droplet spectrum adjustments aim at reducing evaporative losses during the spraying of plant protection products. Consequently, they increase the quality of the application, as well as reduce the environmental impacts and the risk of contamination caused by operators, who do not need to touch any part of the spraying machine.

The system changes the droplet size without changing the previously selected spray volume when spray nozzles are automatically changed, while similar liquid flows are maintained. In this case, the technician in charge is responsible for pre-selecting hydraulic nozzle models capable of enabling an efficient application based on the

Table 1: Psychrometric air conditions during the tests

\begin{tabular}{|c|c|c|c|c|c|c|}
\hline \multirow{2}{*}{$\begin{array}{l}\text { Hydraulic } \\
\text { nozzle }\end{array}$} & \multicolumn{3}{|c|}{$\mathrm{VPD}<20 \mathrm{hPa}$} & \multicolumn{3}{|c|}{$\mathrm{VPD}>20 \mathrm{hPa}$} \\
\hline & T. $\left({ }^{\circ} \mathbf{C}\right)$ & R.H. (\%) & VPD (hPa) & T. $\left({ }^{\circ} \mathbf{C}\right)$ & R.H. (\%) & VPD (hPa) \\
\hline JA-2 & $22-23$ & $49-51$ & $13.22-14.33$ & $29-31$ & $38-41$ & $23.63-27.85$ \\
\hline CVIA-015 & $22-25$ & $49-51$ & $13.22-15.84$ & $29-31$ & $39-41$ & $24.03-27.4$ \\
\hline
\end{tabular}

Table 2: Volumetric median diameter of JA-2 and CVIA-015 nozzles based on target distance and on climate conditions

\begin{tabular}{|c|c|c|c|c|c|c|}
\hline \multirow{2}{*}{$\begin{array}{l}\text { Hydraulic } \\
\text { nozzle }\end{array}$} & \multicolumn{2}{|c|}{ Dist.0.5 m } & \multicolumn{2}{|c|}{ Dist.1.0 m } & \multicolumn{2}{|c|}{ Dist.1.5 m } \\
\hline & VPD $<20$ & VPD $>20$ & VPD $<20$ & VPD $>20$ & VPD $<20$ & VPD $>20$ \\
\hline JA-2 & $500 \mathrm{aA}$ & $716 \mathrm{aB}$ & $353 \mathrm{aA}$ & $448 \mathrm{aA}$ & $370 \mathrm{aA}$ & $592 \mathrm{aB}$ \\
\hline CVIA-015 & $701 \mathrm{bA}$ & $1065 \mathrm{bB}$ & $678 \mathrm{bA}$ & $744 \mathrm{bA}$ & $706 \mathrm{bA}$ & $844 \mathrm{bA}$ \\
\hline
\end{tabular}

At each distance, means followed by the same lowercase letter in the column, and by the same uppercase letter on the line, did not differ from each other in the Tukey test, at $5 \%$ probability level.

Table 3: Density of droplets produced by JA-2 and CVIA-015 nozzles based on target distance and on climate conditions

\begin{tabular}{|c|c|c|c|c|c|c|}
\hline \multirow{2}{*}{$\begin{array}{l}\text { Hydraulic } \\
\text { nozzle }\end{array}$} & \multicolumn{2}{|c|}{ Dist.0.5 m } & \multicolumn{2}{|c|}{ Dist.1.0 m } & \multicolumn{2}{|c|}{ Dist.1.5 m } \\
\hline & VPD $<20$ & VPD $>20$ & $V P D<20$ & VPD $>20$ & VPD $<20$ & VPD $>20$ \\
\hline JA-2 & $184 \mathrm{aA}$ & $128 \mathrm{aB}$ & $167 \mathrm{aA}$ & $159 \mathrm{aA}$ & $133 \mathrm{aA}$ & $100 \mathrm{aB}$ \\
\hline CVIA-015 & $84 \mathrm{bA}$ & $75 \mathrm{bA}$ & $64 \mathrm{bA}$ & $56 \mathrm{bA}$ & $60 \mathrm{bA}$ & $52 \mathrm{bA}$ \\
\hline
\end{tabular}

At each distance, means followed by the same lowercase letter in the column, and by the same uppercase letter on the line, did not differ from each other in the Tukey test, at 5\% probability level. 
Robson Shigueaki Sasaki et al.

Table 4: SPAN index (adm) enabled by JA-2 and CVIA-015 nozzles based on target distance and on climate conditions

\begin{tabular}{|c|c|c|c|c|c|c|}
\hline \multirow{2}{*}{$\begin{array}{l}\text { Hydraulic } \\
\text { nozzle }\end{array}$} & \multicolumn{2}{|c|}{ Dist.0.5 m } & \multicolumn{2}{|c|}{ Dist.1.0 m } & \multicolumn{2}{|c|}{ Dist.1.5 m } \\
\hline & VPD $<20$ & VPD $>20$ & $V P D<20$ & VPD $>20$ & $V P D<20$ & VPD $>20$ \\
\hline JA-2 & $1.2 \mathrm{aA}$ & $1.2 \mathrm{aA}$ & $1.0 \mathrm{aA}$ & $1.1 \mathrm{aA}$ & $0.9 \mathrm{aA}$ & $1.2 \mathrm{aA}$ \\
\hline CVIA-015 & $1.0 \mathrm{aA}$ & $1.1 \mathrm{aA}$ & $0.9 \mathrm{aA}$ & $1.1 \mathrm{aA}$ & $1.0 \mathrm{aA}$ & $1.2 \mathrm{aA}$ \\
\hline
\end{tabular}

At each distance, means followed by the same lowercase letter in the column, and by the same uppercase letter on the line, did not differ from each other in the Tukey test, at $5 \%$ probability level.

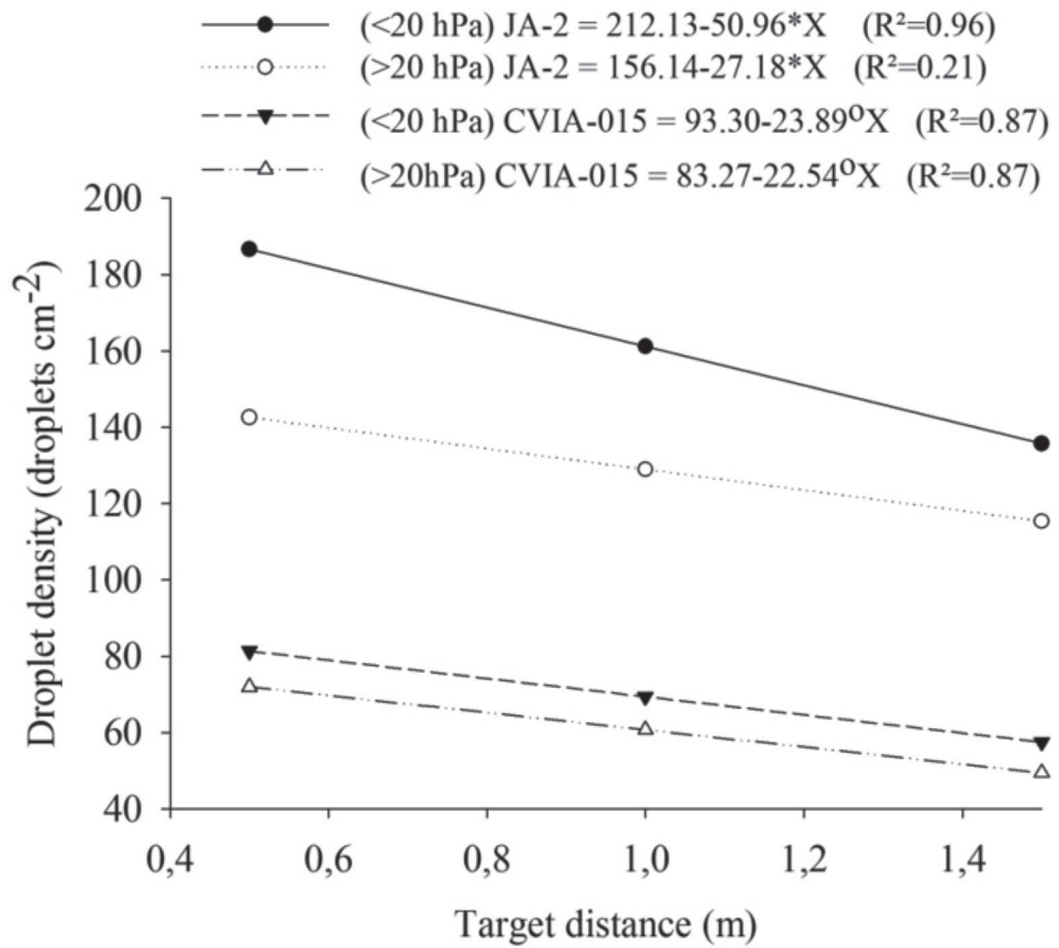

Figure 4: Density of droplets enabled by JA-2 and CVIA-015 nozzles at different target distances and VPDs. $*$ Significant in the $\mathrm{t}$ test at $5 \%$ probability level, ${ }^{\circ}$ Significant in the t test at $10 \%$ probability level.

product to be applied, on the target and on local meteorological conditions. It is well-known that small droplets increase target coverage (Ferguson et al, 2016); however, they may favor drift, evaporation and atmosphererelated losses (Craig et al, 2014; Lasmar \& Cunha, 2016). According to recommendations by Nascimento et al. (2012), the spray droplets must be big enough not to be lost due to evaporation and small enough to enable good target coverage.

\section{CONCLUSIONS}

Electric solenoid valves are applicable to the automation of hydraulic nozzle replacement in hydropneumatic sprayers.

The automatic nozzle replacement can improve spray quality due to changes in psychrometric conditions such as temperature and relative air humidity.

High VPD conditions reduced the density of smalldiameter droplets on the target by up to $30.5 \%$.
Air-induction spray nozzles produce droplets less subject to the influence of psychrometric air conditions.

\section{ACKNOWLEDGEMENTS, FINANCIAL SUPPORT AND FULL DISCLOSURE}

To the Federal Institute of Minas Gerais for the concession of a scholarship.

\section{REFERENCES}

Alvarenga CB, Teixeira MM, Zonier S, Cecon PR, Siqueira DL, Rodrigues DE, Sasaki RS \& Rinaldi PCN (2014) Efeito do déficit de pressão de vapor d'água no ar na pulverização hidropneumática em alvos artificiais. Bioscience Journal, 30:182193.

Alvarenga CB, Teixeira MM, Zolnier S, Sasaki RS \& Rinaldi PCN (2013) Controle automático do espectro de gotas de pulverizador hidro-pneumático em função do déficit de pressão de vapor d'água no ar. Pesquisa Agropecuária Tropical, 43:26-33.

Craig IP, Hewitt A \& Terry H (2014) Rotary Atomiser design requirements for optimum pesticide application efficiency. Crop Protection, 66:34-39. 
Creech CF, Henry RS, Fritz BK \& Kruger GR (2015) Influence of Herbicide Active Ingredient, Nozzle Type, Orifice Size, Spray Pressure, and Carrier Volume Rate on Spray Droplet Size Characteristics. Weed Technology, 29:298-310.

Cunha JPAR, Lasmar O, Ramos AMR \& Alvez GS (2016) Evaporations time of droplets containing thiamethoxam and adjuvants sprayed on sugarcane leaves. Pesquisa Agropecuária Tropical, 46:01-08.

Ferreira DF (2011) Sisvar: a computer statistical analysis system. Ciência e Agrotecnologia, 35:1039-1042.

Lasmar O \& Cunha JPAR (2016) Evaporation time of droplets containing thiamethoxam and adjuvants on hydrophilic, hydrophobic and lipophilic surfaces under different air relative humidities. Bioscience Journal, 32:108-114.

Machado ODC, Alonço AS, Francetto TR \& Carpes DP (2015) Acurácia e tempos de resposta de máquinas para aplicação de defensivos agrícolas à taxa variável. Ciência Rural, 45:440449 .

Maciel CFS, Teixeira MM, Fernandes HC, Zolnier S \& Cecon PR (2016) Droplet spectrum at diferente vapour pressure déficits. Revista Ciência Agronômica, 47:41-46

Maciel CF, Teixeira MM, Zolnier S, Fernandes HC \& Santiago H (2017a) Sprayed liquid loss due to evaporation in diferente psychrometric conditions. Revista Brasileira de Ciências Agrárias, $12: 244-250$

Maciel CFS, Teixeira MM, Fernandes HC, Vitório EL \& Cecon PR (2017b) Distribuição volumétrica e espectro de gotas das pontas hidráulicas LD 11002 E MAG-2. Revista Engenharia na Agricultura, 25:183-199.

Maciel CF, Teixeira MM, Zolnier S, Fernandes HC \& Cecon PR (2018) Droplet spectrum of a spray nozzle under different weather conditions. Revista Ciência Agronômica, 49:430-436.

Nascimento AB, Oliveira GM, Balan MG, Higashiara LR \& Abi Saab OJG (2012) Deposição de glifosato e utilização de adjuvantes para diferentes pontas de pulverização e horário de aplicação. Revista Brasileira de Tecnologia Aplicada nas Ciências Agrárias, 05:105-116.
Gandolfo MA, Carvalho FK, Chechetto RG, Gandolfo UD \& Moraes EDD (2014) Effect of working pressure at different spray nozzles on drift quantification in wind tunnel. Engenharia Agrícola, 34:66-73.

Ferguson JC, O'Donnel CC, Chauhan BS, Adkins SW, Kruger GR, Wang R, Ferreira PHU \& Hewitt AJ (2015) Determining the uniformity and consistency of droplet size across spray drift reducing nozzles in a wind tunnel. Crop Protection, 76:01-06.

Ferguson JC, Chechetto RG, Hewitt AJ, Chauhan BS, Adkins SW, Kruger GR \& O'Donnell CC (2016) Assessing the deposition and canopy penetration of nozzles with different spray qualities in an oat (Avena sativa L.) canopy. Crop Protection, 81:14-19.

Pereira FJS (2006) Sistema de comutação de pontas na barra de pulverização para ajuste do tamanho de gotas às condições climáticas e aplicação em taxas variáveis. Tese de Doutorado. Universidade Estadual Paulista, Botucatu. 125p.

Queiroz HS \& Reis EF (2015) Deposição de calda de pulverização hidráulica de uso agrícola em condições de controladas de temperatura. Fronteiras: Journal of Social, Technological and Environmental Science, 04:230-240.

Sasaki RS, Teixeira MM, Fernandes HC, Zolnier S, Maciel CFS \& Alvarenga CB (2016) Droplets spectrum of air-assisted boom sprayers under different environmental and operational conditions. Revista Brasileira de Engenharia Agrícola e Ambiental, 20: 92-96.

Xu L, Zhu H, Ozkan HE \& Thistle HW (2010) Evaporation rate and development of wetted area of water droplets with and without surfactant at different locations on waxy leaf surfaces. Biosystems Engineering, 106:58-67.

Yu Y, Zhu H, Ozkan HE, Derksen RC \& Krause CR (2009) Evaporation and deposition coverage area of droplets containing insecticides and sprays additives on hydrophilic, hydrophobic, and crabapple leaf surfaces. Transactions of the ASABE, 52:3949 . 